Brief Note

\title{
Natural hybridization between Gossypium mustelinum and exotic allotetraploid cotton species
}

\author{
P.A.V. Barroso ${ }^{2}$ \\ GO, Brasil \\ Corresponding author: I.P.P. de Menezes \\ E-mail: ivan.menezes@ifgoiano.edu.br \\ Genet. Mol. Res. 14 (4): 14177-14180 (2015) \\ Received June 26, 2015 \\ Accepted September 29, 2015 \\ Published October 29, 2015 \\ DOI http://dx.doi.org/10.4238/2015.October.29.40
}

I.P.P. de Menezes ${ }^{1}$, J.O. da Silva ${ }^{1}$, G. Malafaia ${ }^{1}$, R.D.D. Silveira ${ }^{1}$ and

'Laboratório de Genética Molecular, Instituto Federal Goiano, Urutaí, GO, Brasil 'Laboratório de Biotecnologia, Embrapa Arroz e Feijão, Santo Antônio de Goiás,

\begin{abstract}
Cotton has been collected in Brazil for decades for its conservation, evaluation, and the use of its genetic resources. Gossypium mustelinum is an allotetraploid cotton species that only occurs in Brazil, and little is known about its genetic potential for improvement. However, the species is threatened by habitat fragmentation and interspecific hybridization with exotic species of cotton. In this study, we investigated the rate of natural hybridization in two populations of G. mustelinum in Bahia, Brazil, with $G$. hirsutum and $G$. barbadense using a set of microsatellite markers.
\end{abstract}

Key words: Hybridization; Wild cotton; SSR molecular marker; Conservation 


\section{INTRODUCTION}

Gossypium mustelinum is the only wild cotton native to Brazil. It mainly occurs along the margins of dammed rivers that have undergone major modifications for local agricultural development (Menezes et al., 2014a), and upland cotton cultivars have spread to its natural habitat. Herbaceous cotton barns are often in close proximity to wild cotton, due to the use of cotton lumps in animal feed (Barroso et al., 2010; Alves et al., 2013), which can facilitate interspecific crosses because the species are sexually compatible allotetraploids.

Interspecific hybridization generates new genotype combinations, which can threaten the integrity of the variability of the receiving population and increase the complexity of maintaining in situ natural populations (Ellstrand et al., 1999; Alexander, 2010). Interspecific hybridization is a conservation threat to cotton (Groot et al., 2003), but was initially characterized as a rare event by Wendel et al. (1994) using a limited number of isoenzymatic markers. Using microsatellite markers, Barroso et al. (2010) and Alves et al. (2013) reported the absence or low occurrence of interspecific crosses.

The reproductive system of cotton is mixed, with outcrossing and autogamous rates dependent on the presence of pollinators (Borém et al., 2003) and interspecific hybridization dependent on the presence and frequency of other species (Pereira et al., 2012). From the perspective of genetic conservation, elucidating the occurrence of interspecific hybridization of G. mustelinum with other species of cotton can assist in conserving its population. Therefore, the objective of this study was to investigate the occurrence of natural interspecific hybrids of $G$. mustelinum from the data produced by Menezes et al. (2014a,b).

\section{MATERIAL AND METHODS}

Two populations of G. mustelinum were studied: Riacho Jacaré (25 plants) and Riacho Riachão (21 plants), both in Rio de Contas, Bahia, Brazil. These populations were chosen because both $G$. barbadense and $G$. hirsutum occur in the area.

Genomic DNA from each plant was isolated and genotyped. Simple sequence repeat (SSR) markers were selected based on their interspecific polymorphisms, which had been identified in previous studies with G. hirsutum, G. barbadense, and G. mustelinum (Menezes et al., 2014a,b). The SSR data were analyzed for the presence of private alleles and the identity probability in a random set of the molecular markers used. We conducted a comparative analysis for the identification of hybrids.

\section{RESULTS}

As expected, all of the SSR markers were polymorphic. We found 58 private alleles, with 36, 7, and 15 in G. mustelinum from Riacho Jacaré, G. barbadense, and G. mustelinum from Riacho Riachão, respectively. When hybrids between G. mustelinum and G. barbadense were omitted, the total number of private alleles was 66 , and 33,18 , and 15 were found in $G$. mustelinum from Riacho Jacaré, G. barbadense, and G. mustelinum from Riacho Riachão, respectively. There was a low probability of identity $\left(4 \times 10^{-11}\right)$.

Only one $\mathrm{F}_{1}$ hybrid plant (4\% of the plants studied) was found in Riacho Jacaré, and no molecular evidence of interspecific crosses between G. mustelinum and G. hirsutum was found along a stream in Riacho Riachão. However, by studying 12 families, each with 16 descendants, along another stream in Riacho Riachão, we found a $F_{1}$ hybrid of $G$. mustelinum and $G$. hirsutum (Figure 1). This proved to be quite vigorous compared to its wild relative, with germination and early 
vegetative and reproductive growth.

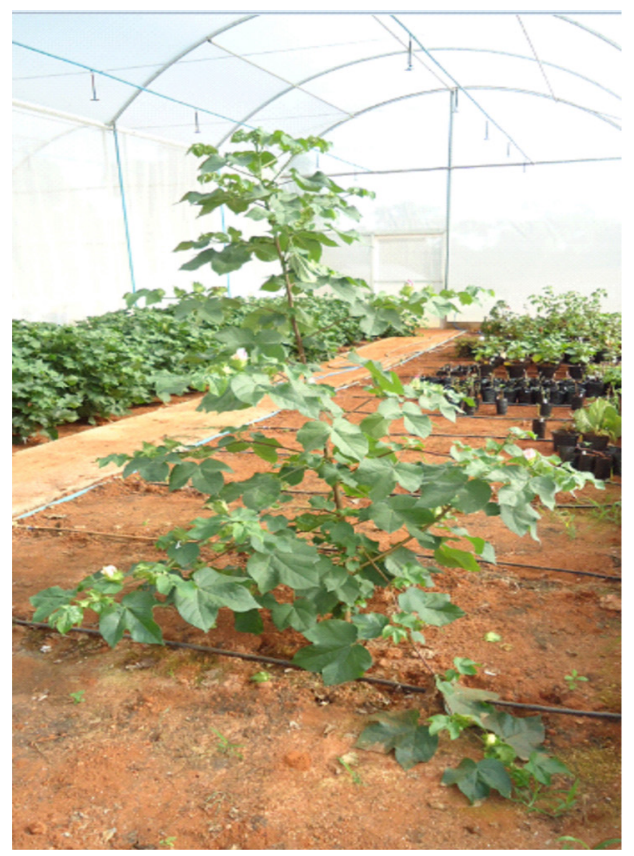

Figure 1. $F_{1}$ hybrid of $G$. mustelinum and G. hirsutum.

\section{DISCUSSION}

The results of this study indicate that there are interspecific introgression events in populations of G. mustelinum under natural conditions. As discussed by Menezes et al. (2014a), there is morphological evidence of G. barbadense introgressions in the G. mustelinum population in Riacho Jacaré, although molecular evidence was not found with the SSR markers used, except for one $F_{1}$ hybrid. Another hybrid, derived from seeds collected in situ from the Riachão stream population, was also detected, and confirmed using SSR markers. To judge by the small size of upland cotton coops and consequently the lower proportions of pollen produced sympatrically with wild populations, one would expect few hybridization events given that pollen competition is a partial reproductive barrier in cotton (Pereira et al., 2012). However, when considering the population size of Riacho Riachão, this hybrid is $5 \%$ of its composition, an event that is no longer defined as rare. The establishment and expansion of upland cotton may lead to an increase in the rate of hybridization (Pereira et al., 2012), which may compromise the integrity of the wild gene pool (Freire, 2002).

Currently, interspecific gene flow does not affect the conservation of wild cotton, probably because of genomic preferences related to pollen receptor status (Adams and Wendel, 2004). However, preventive measures must be taken, because the rate of interspecific crosses is positively correlated with the frequency of exotic cotton. Therefore, coexistence between them should be avoided. 


\title{
ACKNOWLEDGMENTS
}

\author{
To Empresa Brasileira de Pesquisa Agropecuária (EMBRAPA), Financiadora de Estudos \\ e Projetos (FINEP) and IF Goiano Campus Urutaí for financing support.
}

\section{REFERENCES}

Adams KL and Wendel JF (2004). Exploring the genomic mysteries of polyploidy in cotton. Biol. J. Linn. Soc. 82: 573-581.

Alexander HM (2010). Disease in natural plant populations, communities, and ecosystems: insights into ecological and evolutionary processes. Plant Dis. 5: 492-502.

Alves MF, Barroso PAV, Ciampi AY, Hoffmann LV, et al. (2013). Diversity and genetic structure among subpopulations of Gossypium mustelinum (Malvaceae). Genet. Mol. Res. 12: 97-609.

Barroso PAV, Hoffmann LV, Batista CE, Freitas RB, et al. (2010). In situ conservation and genetic diversity of three populations of Gossypium mustelinum Miers (ex Watt). Genet. Resour. Crop Evol. 57: 343-349.

Borém A, Freire EC, Penna JC and Barroso PAV (2003). Considerations about cotton gene escape in Brazil: a review. Crop Breed. Appl. Biotechnol. 3: 315-332.

Ellstrand NC, Prentice HC and Hancock JF (1999). Gene flow and introgression from domesticated plants into their wild relatives. Annu. Rev. Ecol. Evol. Syst. 30: 539-563.

Freire EC (2002). Viabilidade de cruzamentos entre algodoeiros transgênicos e comerciais e silvestres do Brasil. Rev. Bra. Ol. Fibro. 1: 465-470.

Groot MHM, Wiel CCM, Tienderen PH andNijs HCM (2003). Hybridization and introgression between crops and wild relatives. University of Amsterdamand Plant Research International.

Menezes IPP, Gaiotto FA, Hoffmann LV, Ciampi AY, et al. (2014a). Genetic diversity and structure of natural populations of Gossypium mustelinum, a wild relative of cotton, in the basin of the De Contas River in Bahia, Brazil. Genetica 142: 99-108.

Menezes IPP, Gaiotto FA, Suassuna ND, Hoffmann LV, et al. (2014b). Susceptibility of Gossypium mustelinum populations to the main cotton diseases in Brazil. J. Agr. Sci. 6: 39-47.

Pereira GS, Sousa RL, Araújo RL, Silva EF, et al. (2012). Selective fertilization interspecific crosses of allotetraploid species Gossypium. Botany 90: 159-166.

Wendel JF, Rowley R, MCD Stewart J (1994). Genetic diversity in and phylogenetic relationships of the Brazilian endemic cotton, Gossypium mustelinum (Malvaceae). Plant. Syst. Evol. 192: 49-59. 